\title{
Influence of partial replacement of sand with copper slag on the thermal properties of hardened concrete
}

\author{
Łukasz Majewski ${ }^{1}$, Roman Jaskulski ${ }^{2}$, Wojciech Kubissa ${ }^{3}$ \\ Faculty of Civil Engineering, Mechanics and Petrochemistry, Warsaw University of Technology, Plock, Poland \\ E-mail: ${ }^{1}$ lukasz.majewski@pw.edu.pl (corresponding author)
}

\begin{abstract}
The article presents the results of testing the effect of partial replacement of sand with fine copper slag waste on the thermal properties of hardened concrete. The impact of the replacement on mechanical properties (ie. compressive and tensile strength of concrete) was also investigated. The thermal properties of the concrete were determined using the non-stationary method with the ISOMET 2114 device. Tests were performed on concrete containing three different types of cement (CEM I, CEM II and CEM III). A total cement content of $360 \mathrm{~kg} / \mathrm{m}^{3}$ was assumed in the compositions of all concrete mixes with a water-cement ratio of 0.45 . Replacing $66 \%$ of the sand volume with copper slag waste caused a decrease in thermal conductivity by about $4-8 \%$ in relation to the reference concrete. In addition, the compressive strength of concrete containing copper slag increased by about from $4-21 \%$ in relation to the reference concrete.
\end{abstract}

Keywords: concrete technology, copper slag, thermal properties, thermal conductivity.

\section{Introduction}

Copper slag has been a subject of great interest for some time as a sustainable construction material (Dhir, de Brito, Mangabhai, \& Lye, 2017; Murari, Siddique, \& Jain, 2015; Prem, Verma, \& Ambily, 2018). Utilizing of the copper slag in building industry has a twofold ecological advantages. On the one hand, it saves natural resources, on the other it is a form of reuse of industrial waste, so it does not have to be stored on landfills. Copper slag is widely used, among others as a material partially or completely replacing sand in concretes and mortars (Al-Jabri, Al-Saidy, \& Taha, 2011; Kubissa, Jaskulski, \& Simon, 2017; Prem et al., 2018). One of the chapters of Dhir et al. book (Dhir et al., 2017) is devoted to this application. The authors elaborated it on the basis of selected 125 studies undertaken since 1989, which gives an average of 5 studies a year, and this is certainly only a part of the papers devoted to this subject.

Copper slag as fine aggregate is widely used. Its use was tested both in lightweight concrete (Jaskulski \& Kubissa, 2018) and in prefabricated heavy concrete elements (Kubissa, Jaskulski, $\mathrm{Ng}$, \& Chen, 2018). Its pozzolanic properties and synergic increase in mechanical properties of material when used together with fly ash make it a valuable material for the preparation of CLSM mixtures with very low cement content (Jaskulski \& Kubissa, 2019). Such mixtures work very well as a backfill of various linear infrastructure, among others due to the ease and speed of incorporation. In addition, in case of a breakdown or the need for refurbishment or modernization, such a backfill can be removed without the use of heavy equipment. The universality of use of copper slag proves the possibility of its use in highstrength concrete (Al-Jabri, Hisada, Al-Saidy, \& Al-Oraimi, 2009) as well as in ultra-high performance concrete (Ambily et al., 2015).

Copper slag waste used in concrete mixtures, which test results are presented in this paper is a residual of the surface blast cleaning process in which the original copper slag is also used as a replacement for sand. Copper slag waste differs from the original material in that its grain size is finer and the grain shape is less edgy. It may contain also some impurities remaining after the surface blast cleaning process. This, however, does not adversely affect its properties, thanks to which it is used as a substitute for sand.

Copper slag waste, depending on whether it cools slowly in the air or is subjected to rapid cooling with water, may contain from 5 to $98 \%$ glassy phase (Kuterasińska \& Król, 2015), which due to its irregular structure has significantly lower thermal conductivity than the crystalline phase. This means that containing 25 to $41 \%$ of $\mathrm{SiO} 2$ copper slag (Shi, Meyer, \& Behnood, 2008) used instead of sand, which usually contains about $98 \%$ of the crystalline form of $\mathrm{SiO} 2$, can lower the thermal conductivity of the material (eg. concrete or mortar). Preliminary confirmation of this effect can be found in the paper of Jaskulski (Jaskulski, Reiterman, \& Kubissa, 2017). However, those preliminary results require confirmation, hence the need for further research. 
Such research was undertaken and the paper presents the results of investigations of thermal properties of concrete, in which two thirds of the sand was replaced by copper slag waste. For comparative purposes, tests of concrete with sand were also performed. Concrete mixtures were prepared using three different types of cement, maintaining in all cases a constant value of the w/c ratio. Due to the deterioration of the workability of concrete mixes with copper slag waste, additional series with this material were prepared, in which a larger amount of superplasticizer was used to achieve consistency similar to concrete with sand. In addition to thermal properties, the compressive strength and tensile splitting strength of the concrete were also investigated. The details of the research and the results are presented further in the paper.

\section{Materials and methods}

\section{Materials}

Three types of Portland cement compliant with PN-EN 197-1 (Polish Committee for Standardization, 2011a), i.e. CEM I 42.5R and CEM III/A 42.5N - LH/HSR/NA produced by Górażdże Cement Plant as well as CEM II/B-V 42.5N produced by Lafarge Cement Plant, were used to prepare concrete mixtures. Basic physical and chemical properties presented by the cement manufacturer are shown in Table 1 . A total cement content of $360 \mathrm{~kg} / \mathrm{m}^{3}$ was assumed in the compositions of all concrete mixes with a water-cement ratio of 0.45 .

Table 1. Basic physical and chemical properties of the cement

\begin{tabular}{|c|c|c|c|c|c|c|c|c|}
\hline \multirow{2}{*}{ Type of cement } & \multicolumn{2}{|c|}{ Setting time } & \multirow{2}{*}{$\begin{array}{l}\text { Compressive } \\
\text { strength after } \\
28 \text { days } \\
{[\mathrm{MPa}]}\end{array}$} & \multirow{2}{*}{$\begin{array}{c}\text { Specific surface area } \\
\text { by Blaine's method } \\
{\left[\mathrm{cm}^{2} / \mathrm{g}\right]}\end{array}$} & \multirow{2}{*}{$\begin{array}{l}\text { Specific } \\
\text { density } \\
{\left[\mathrm{g} / \mathrm{cm}^{3}\right]}\end{array}$} & \multirow{2}{*}{$\begin{array}{l}\mathrm{SO}_{3} \\
{[\%]}\end{array}$} & \multirow{2}{*}{$\begin{array}{c}\mathrm{Cl} \\
{[\%]}\end{array}$} & \multirow{2}{*}{$\begin{array}{c}\mathrm{Na}_{2} \mathrm{O}_{\mathrm{ec}} \\
{[\%]}\end{array}$} \\
\hline & $\begin{array}{l}\text { Start } \\
{[\mathrm{min}]}\end{array}$ & $\begin{array}{l}\text { End } \\
{[\mathrm{min}]}\end{array}$ & & & & & & \\
\hline CEM I 42.5R & 176 & 231 & 57.9 & 3538 & 3.10 & 2.52 & 0.063 & 0.60 \\
\hline CEM II/B-V 42.5N & 203 & 294 & 50.6 & 4888 & 2.82 & 2.66 & 0.063 & 1.12 \\
\hline $\begin{array}{l}\text { CEM III/A 42.5N } \\
\text { LH/HSR/NA }\end{array}$ & 201 & 306 & 58.3 & 4165 & 2.91 & 2.30 & 0.055 & 0.70 \\
\hline
\end{tabular}

Crushed granite aggregates $2 / 8 \mathrm{~mm}$ and $8 / 16 \mathrm{~mm}$ were used as coarse aggregates. River sand of $0 / 2 \mathrm{~mm}$ and copper slag of $0 / 2 \mathrm{~mm}$ were used as fine aggregates. Fine and coarse aggregates were stored in laboratory air-dry conditions. Grading curves of the aggregates and its mixtures are shown in Figure 1. The specific density of the aggregates was equal to $2.65 \mathrm{~g} / \mathrm{cm}^{3}$ for sand, $2.67 \mathrm{~g} / \mathrm{cm}^{3}$ for granite and $2.99 \mathrm{~g} / \mathrm{cm}^{3}$ for copper slag. Chemical compositions of the copper slag was as follows: $45.9 \% \mathrm{SiO}_{2}, 25.3 \% \mathrm{CaO}, 4.6 \% \mathrm{FeO}, 12.2 \mathrm{Al}_{2} \mathrm{O}_{3}, 9.1 \mathrm{MgO}, 0.8 \% \mathrm{Cu}$.

Tap water from the municipal water supply system was used as mixing water.

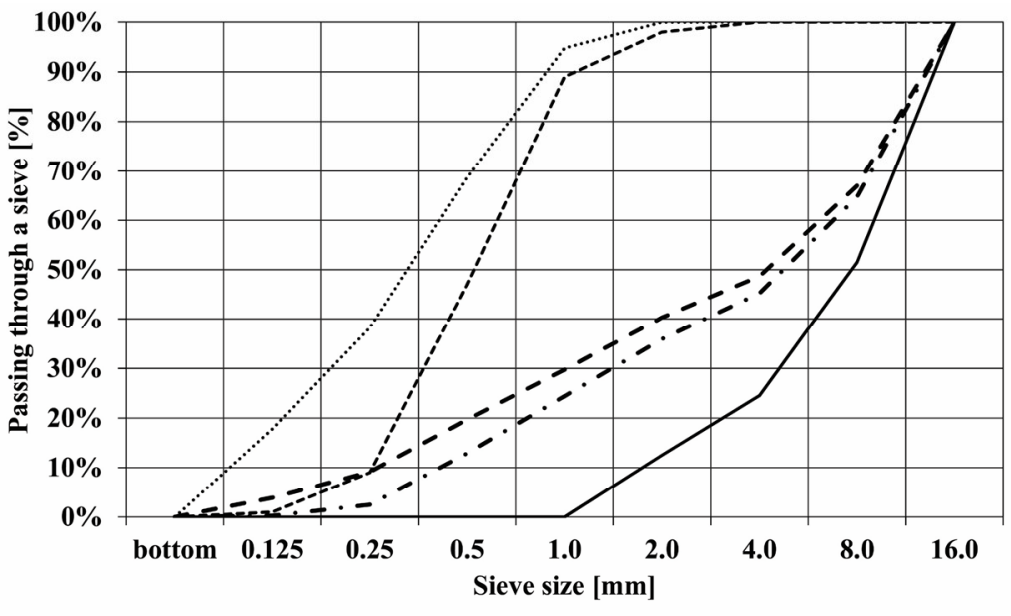

-.... CS 0/2 ---Sand 0/2 —Granite 2/16 - - Mix 0\% CS - -Mix 66\% CS

Figure 1. Grading curves of the aggregates and its mixtures

In total, 9 concrete mixtures were prepared. Mix proportions for these concretes are presented in Table 2. Three concrete mixtures containing only sand as fine aggregate were made (series marked with the suffix "0"). The group of these mixtures was a reference. Based on the recipes of these mixtures, another 3 mixtures were prepared in which $66 \%$ of the volume of sand was replaced with copper slag (series marked with the suffix " 66 '). 
Replacement of sand with copper slag negatively affected the workability and consistency of fresh concrete mixes due to the increase in the content of fine particles. The diameter of flow of these mixtures during the flow table consistency test according to PN-EN 12350-5 (Polish Committee for Standardization, 2011b) decreased on average by 9 $\mathrm{cm}$. The change in the consistency class from F2 to F1 may have influenced on the porosity of the hardened concrete and, consequently, its thermal properties. Therefore, another 3 mixtures were made (series marked with the suffix "66/F"). In these dosing of the plasticizer was increased to obtain workability and consistency similar to the reference mixtures. As a plasticizing admixture, the Chryso Optima 100 superplasticizer manufactured by Chryso was used. This admixture complies with the requirements of PN-EN 934-2 (Polish Committee for Standardization, 2012).

Table 2. Proportions of concrete mixtures with natural aggregate and partial replacement of sand with copper slag $\left[\mathrm{kg} / \mathrm{m}^{3}\right]$

\begin{tabular}{|l|c|c|c|c|c|c|c|c|c|}
\hline $\begin{array}{c}\text { Mixture symbol } \\
\text { Ingredient }\left[\mathrm{kg} / \mathrm{m}^{3}\right]\end{array}$ & $\mathrm{I} / 0$ & $\mathrm{I} / 66$ & $\mathrm{I} / 66 / \mathrm{F}$ & $\mathrm{II} / 0$ & $\mathrm{II} / 66$ & $\mathrm{II} / 66 / \mathrm{F}$ & $\mathrm{III} / 0$ & III/66 & III/66/F \\
\hline CEM I 42.5R & 360 & 360 & 360 & 0 & 0 & 0 & 0 & 0 & 0 \\
\hline CEM II/B-V 42.5N & 0 & 0 & 0 & 360 & 360 & 360 & 0 & 0 & 0 \\
\hline CEM III/A 42.5N - LH/HSR/NA & 0 & 0 & 0 & 0 & 0 & 0 & 360 & 360 & 360 \\
\hline Natural sand 0/2 & 598 & 199 & 198 & 587 & 196 & 195 & 591 & 197 & 196 \\
\hline Granite aggregate 2/8 & 621 & 621 & 618 & 610 & 610 & 608 & 614 & 614 & 612 \\
\hline Granite aggregate 8/16 & 659 & 659 & 655 & 659 & 647 & 645 & 651 & 651 & 649 \\
\hline Copper slag 0/2 & 0 & 449 & 447 & 0 & 441 & 440 & 0 & 444 & 443 \\
\hline Water & 162 & 162 & 162 & 162 & 162 & 162 & 162 & 162 & 162 \\
\hline Superplasticizer [\% of cement weight] & $0.65 \%$ & $0.65 \%$ & $1.65 \%$ & $0.70 \%$ & $0.70 \%$ & $1.30 \%$ & $0.80 \%$ & $0.80 \%$ & $1.50 \%$ \\
\hline W/C & 0.45 & 0.45 & 0.45 & 0.45 & 0.45 & 0.45 & 0.45 & 0.45 & 0.45 \\
\hline (W+Sp)/C & 0.457 & 0.457 & 0.467 & 0.457 & 0.457 & 0.463 & 0.458 & 0.458 & 0.465 \\
\hline Flow table test [mm] & 395 & 315 & 410 & 410 & 310 & 415 & 410 & 330 & 440 \\
\hline
\end{tabular}

Methods

Each of the presented concrete mixes was prepared in a laboratory concrete pan mixer. Fresh concrete was casted in two steps into steel moulds and compacted by vibration. For each mixture, 13 cubic specimens of the sizes $100 \times 100 \times 100 \mathrm{~mm}$ were prepared to determine the compressive and tensile strength of concrete, as well as 1 cylindrical specimen of the sizes $150 \times 300 \mathrm{~mm}$ for the determination of thermal properties. All the specimens were demoulded after 2 days and then cured in accordance with PN-EN 12390-2 (Polish Committee for Standardization, 2011c) for the next 26 days. Compressive and tensile splitting strength of concrete was determined on 28 days old cubic specimens. These tests were performed according to standards PN-EN 2390-3 (Polish Committee for Standardization, 2011d) and PN-EN 12390-6 (Polish Committee for Standardization, 2011e), by means of an automatic concrete compression testing machine. A load increase rate of $0.5 \mathrm{MPa} / \mathrm{s}$ was assumed for compression test and rate of $0.05 \mathrm{MPa} / \mathrm{s}$ for tensile splitting test.

The cylindrical specimens were cut into $25 \mathrm{~mm}$ thick slices to obtain specimens for testing the thermal properties. Ten slices were obtained from each cylinder. The slices were put into water container and stored there until the begining of the test.

Determination of thermal conductivity, thermal diffusivity and volumetric heat capacity was carried out using the multifunction measuring tool ISOMET 2114 using its surface probe. ISOMET 2114 is a hand-held measuring instrument for direct measurement of heat transfer properties of a wide range of isotropic materials e.g. structural and cellular insulating materials, plastics, glasses and minerals (Applied Precision Ltd., 2011).The determination of thermal properties is carried out by means of the non-stationary heat transfer method. Measurement is based on analysis of the temperature response of the tested material to heat impulses. This is a variant of the hot-plate method. The test of a single specimen takes place in two steps. In the first step, after the tested material reach the thermal equilibrium, the specimen is heated with the previously determined power. In the second step, after the heating stopped, the specimen is cooling down. The rate of temperature increase during heating and the cooling rate are the output data for determining the thermal properties by the internal algorithm of the measuring device.

As it was mentioned before, the determination of thermal properties of concrete was performed on slices cut from cylindrical specimens. Specimens were tested in two states of water saturation. At first, specimens fully saturated with water were tested. For this purpose, the specimens were stored in water for several weeks before the test to obtain the maximum degree of water saturation that can be achieved in a natural way. After saturating the specimens with water, they were tested using ISOMET 2114 device. During the test, the specimens were protected from drying out. After the 
test, the wet samples were dried in a drying oven at $65^{\circ} \mathrm{C}$ to constant mass. Then the dried specimens were allowed to cool and then tested again.

Testing of the same specimens in two states of humidity allowed to determine the limits of the range, in which the measured thermal properties of concrete change. This made it possible to compare the values obtained with each other due to the identic conditions of the specimens during the test. Additionally, thanks to this, a reference was created, according to which it is possible to assess the thermal properties of concrete in other, more likely than the tested, saturation states.

\section{Results and results disscussion}

\section{Compressive and tensile splitting strength of concrete}

The average compressive and tensile splitting strength of the tested concrete after 28 days of curing are shown in Table 3 as well as in Figures 2 and 3.

Table 3. The average compressive and tensile splitting concrete strength after 28 days of curing

\begin{tabular}{|c|c|c|c|c|c|c|c|c|c|}
\hline \multirow{2}{*}{\begin{tabular}{|c|c|c|c|c|c|c|} 
Parameter [MPa] \\
\cline { 2 - 11 }
\end{tabular}} & I/0 & II/0 & III/0 & I/66 & II/66 & III/66 & I/66/F & II/66/F & III/66/F \\
\hline Compressive strength & 55.0 & 53.3 & 60.2 & 54.6 & 56.5 & 60.4 & 66.4 & 61.3 & 62.5 \\
\hline - standard deviation & 1.68 & 1.79 & 2.15 & 1.41 & 1.13 & 1.24 & 0.59 & 1.03 & 1.64 \\
\hline Tensile splitting strength & 3.20 & 3.79 & 3.20 & 3.27 & 2.98 & 3.52 & 3.79 & 3.85 & 4.12 \\
\hline - standard deviation & 0.40 & 0.42 & 0.15 & 0.57 & 0.33 & 0.64 & 0.32 & 0.11 & 0.28 \\
\hline
\end{tabular}

The t-student statistical test, i.e. the significance test of two averages for independent specimens, was used to compare the strength values of individual concretes for compression and tension. The purpose of the test was to determine whether the obtained average values should be considered as statistically different. The significance level of the test $\alpha=0.05$ was assumed. Before carrying out this test, it was necessary to assume the equality of variances of the results for the compared concrete mixtures. For this purpose, the Fisher-Snedecor test was carried out. For all concrete mixtures, the assumption of equality of variance was found.

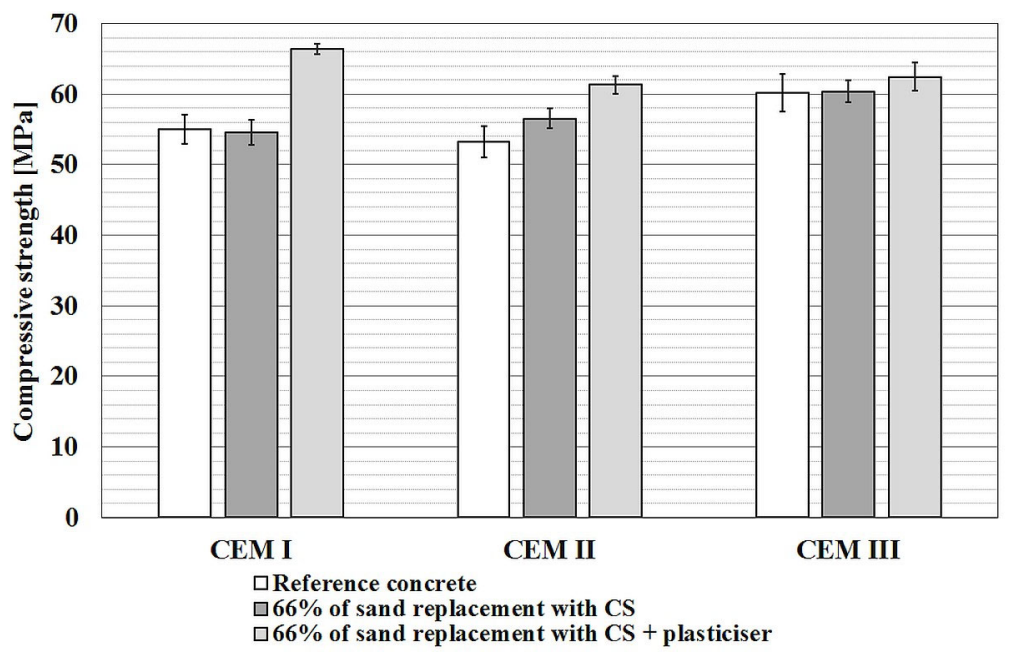

Figure 2. Average cube compressive strength of concretes at 28-days of curing

The obtained average compressive strength of concrete was: from 55.0 to $60.2 \mathrm{MPa}$ for reference concrete, from 54.6 to $60.4 \mathrm{MPa}$ for concrete containing copper slag, from 61.3 to $66.4 \mathrm{MPa}$ for concretes containing copper slag and increased dose of plasticizing admixture. The type of binder used had a significant impact on the compressive strength of the concrete.

Replacing the sand with copper slag without increasing the dose of plasticizer slightly affected the average compressive strength of concrete. The obtained strength values were similar to the strength of reference concrete. The compressive strength was found equal for concretes containing CEM I and CEM III. Whereas that the average strength of concrete containing CEM II was higher by about $6 \%$ compared to the reference concrete. These statements resulted from the performed t-student tests. 
An increase in the average compressive strength of concrete containing copper slag and an increased dose of plasticizing admixture was observed (series marked with the suffix " $66 / \mathrm{F}$ "). This increase, in reference to the reference concrete, was equal: $20.7 \%$ for concrete containing CEM I, $15.1 \%$ for concrete containing CEM II, and $3.8 \%$ for concrete containing CEM III. Obtaining in these series consistencies and workability close to the reference concrete enabled to obtain better compaction of the mixture, which in turn increased the strength values.

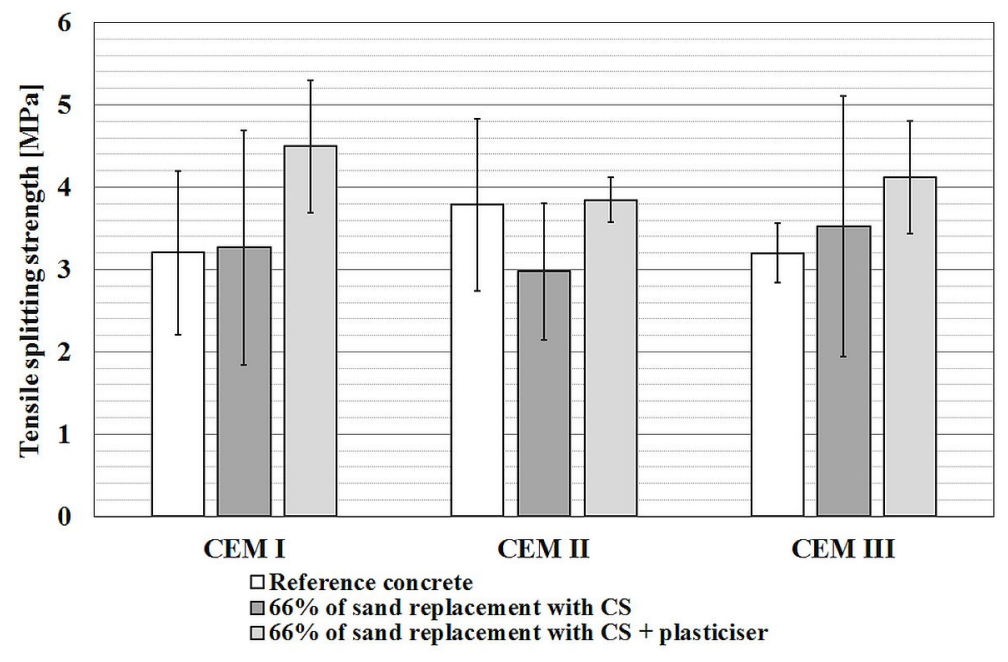

Figure 3. Average cube tensile splitting strength of concretes at 28-days of curing

There is no specific trend of tensile splitting strength of the concrete. The average values of this strength for most of the concretes are not significantly different from the strength values obtained for the reference concrete because of high value of standard deviation. Only the strength of the concrete based on CEM I and containing copper slag and the increased dose of plasticizer (series I/66/F) shows a significantly higher value compared to the reference concrete. The increase of the value of strength was equal $40.3 \%$ (1.3 MPa).

Thermal conductivity

Average thermal conductivity coefficients of the tested concretes are presented in Table 4 as well as in Figure 4.

Table 4. Average thermal conductivity coefficients of tested concrete depending on the state of saturation

\begin{tabular}{|c|c|c|c|c|c|c|c|c|c|c|}
\hline \multirow[b]{2}{*}{ Condition } & \multirow{2}{*}{$\begin{array}{c}\text { Thermal } \\
\text { conductivity } \\
\text { coefficient } \\
{[\mathrm{W} /(\mathrm{m} \cdot \mathrm{K})]}\end{array}$} & \multicolumn{9}{|c|}{ Concrete mixture designation } \\
\hline & & $\mathrm{I} / 0$ & $\mathrm{I} / 66$ & $\mathrm{I} / 66 / \mathrm{F}$ & $\mathrm{II} / 0$ & $\mathrm{II} / 66$ & $\mathrm{II} / 66 / \mathrm{F}$ & $\mathrm{III} / 0$ & III/66 & $\mathrm{III} / 66 / \mathrm{F}$ \\
\hline \multirow{3}{*}{$\begin{array}{l}\text { Specimens fully } \\
\text { saturated with water }\end{array}$} & Mean & 2.49 & 2.39 & 2.28 & 1.84 & 1.73 & 1.76 & 1.78 & 1.66 & 1.69 \\
\hline & Stand. dev. & 0.176 & 0.291 & 0.119 & 0.103 & 0.145 & 0.104 & 0.195 & 0.153 & 0.067 \\
\hline & Averaged & \multicolumn{3}{|c|}{2.39} & \multicolumn{3}{|c|}{1.78} & \multicolumn{3}{|c|}{1.71} \\
\hline \multirow{3}{*}{$\begin{array}{l}\text { Specimens dried to } \\
\text { constant weight }\end{array}$} & Mean & 1.69 & 1.61 & 1.64 & 1.31 & 1.12 & 1.20 & 1.29 & 1.17 & 1.21 \\
\hline & Stand. dev. & 0.126 & 0.108 & 0.093 & 0.036 & 0.064 & 0.074 & 0.075 & 0.076 & 0.044 \\
\hline & Averaged & \multicolumn{3}{|c|}{1.65} & \multicolumn{3}{|c|}{1.21} & \multicolumn{3}{|c|}{1.23} \\
\hline
\end{tabular}

A clear difference in the values of thermal conductivity coefficients determined for both water saturation levels is visible. The values of thermal conductivity coefficients for specimens in the state of full saturation with water are higher by several dozen percent compared to specimens dried to a constant mass. Differences in the value of coefficients are on average: $44.7 \%$ for CEM I, $47.1 \%$ for CEM II and 39.5\% for CEM III. The decisive influence on this was the presence of water, which, filling the free spaces in the concrete, reduced the content of air to a minimum level, which is a good thermal insulator and the influence of heat transfer due its convection in pores is negligible. 


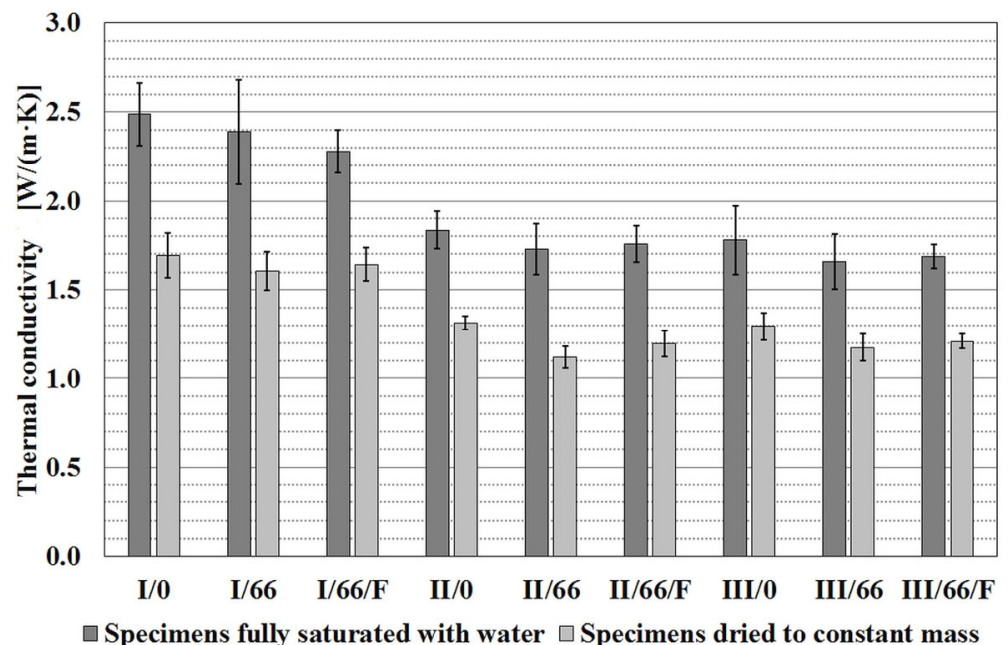

Figure 4. Average thermal conductivity coefficient of tested concrete

The highest values of thermal conductivity coefficients were obtained for concretes containing CEM I. Avereged values were equal: $2.39 \mathrm{~W} /(\mathrm{m} \cdot \mathrm{K})$ for fully saturated state and $1.65 \mathrm{~W} /(\mathrm{m} \cdot \mathrm{K})$ for concrete dried to constant mass. For the other concrete mixtures, much lower values of this coefficient were obtained. These values were $1.78 \mathrm{~W} /(\mathrm{m} \cdot \mathrm{K})$ and $1.21 \mathrm{~W} /(\mathrm{m} \cdot \mathrm{K})$ for concrete with CEM II and $1.71 \mathrm{~W} /(\mathrm{m} \cdot \mathrm{K})$ and $1.23 \mathrm{~W} /(\mathrm{m} \cdot \mathrm{K})$ for concrete with CEM III respectively. For concrete based on these cements, similar values of thermal conductivity coefficients were obtained.

The values of the thermal conductivity coefficient for concrete containing copper slag are close to the values of the coefficient values obtained for reference concrete. As a result of the significance test of two averages, it was found that the differences of the average values of this coefficient are statistically insignificant. Without considering the standard deviation, it can be noticed that the value of thermal conductivity coefficient for concrete containing copper slag is lower than reference concrete. For the fully saturated concrete the decrease in the coefficient value was equal: 4.1-8.5\% for concrete with CEM I, 4.2-5.8\% for concrete with CEM II and 5.0-6.8\% for concrete with CEM III. In case of concrete dried to a constant mass, the decrease was equal: 3.0-5.1\% for concrete with CEM I, 8.8-14.8\% for concrete with CEM II and 6.4-9.2\% for concrete with CEM III.

\section{Volumetric heat capacity}

The obtained values of volumetric heat capacity of the concretes are presented in Table 5.

Table 5. Average values of volumetric heat capacity of tested concretes depending on the state of saturation with water

\begin{tabular}{|c|c|c|c|c|c|c|c|c|c|c|}
\hline \multirow{2}{*}{ Condition } & \multirow{2}{*}{$\begin{array}{c}\text { Volumetric } \\
\text { heat capacity } \\
{\left[\mathrm{MJ} /\left(\mathrm{m}^{3} \cdot \mathrm{K}\right)\right]}\end{array}$} & \multicolumn{9}{|c|}{ Concrete mixture designation } \\
\hline & & $\mathrm{I} / 0$ & $\mathrm{I} / 66$ & $\mathrm{I} / 66 / \mathrm{F}$ & $\mathrm{II} / 0$ & II/66 & $\mathrm{II} / 66 / \mathrm{F}$ & $\mathrm{III} / 0$ & III/66 & $\mathrm{III} / 66 / \mathrm{F}$ \\
\hline \multirow{3}{*}{$\begin{array}{l}\text { Specimens fully } \\
\text { saturated with water }\end{array}$} & Mean & 1.93 & 1.94 & 1.87 & 1.87 & 1.87 & 1.86 & 1.79 & 1.76 & 1.78 \\
\hline & Stand. dev. & 0.15 & 0.21 & 0.13 & 0.12 & 0.12 & 0.15 & 0.09 & 0.09 & 0.06 \\
\hline & Averaged & \multicolumn{3}{|c|}{1.91} & \multicolumn{3}{|c|}{1.87} & \multicolumn{3}{|c|}{1.78} \\
\hline \multirow{3}{*}{$\begin{array}{l}\text { Specimens dried to } \\
\text { constant weight }\end{array}$} & Mean & 1.73 & 1.70 & 1.78 & 1.73 & 1.65 & 1.73 & 1.71 & 1.65 & 1.71 \\
\hline & Stand. dev. & 0.06 & 0.06 & 0.05 & 0.04 & 0.06 & 0.01 & 0.06 & 0.05 & 0.06 \\
\hline & Averaged & \multicolumn{3}{|c|}{1.74} & \multicolumn{3}{|c|}{1.70} & \multicolumn{3}{|c|}{1.69} \\
\hline
\end{tabular}

Replacement of sand with copper slag has no effect on the volumetric heat capacity in relation to the reference concretes.

The average values of the volumetric heat capacity of water saturated concrete prepared with a given cement type show no specific trend. The values for concrete based on the same cement are similar and there are no outliers. In the state of full saturation with water, this parameter takes the average values: $1.91 \mathrm{MJ} /\left(\mathrm{m}^{3} \cdot \mathrm{K}\right)$ for CEM I, $1.87 \mathrm{MJ} /\left(\mathrm{m}^{3} \cdot \mathrm{K}\right)$ for CEM II and $1.78 \mathrm{MJ} /\left(\mathrm{m}^{3} \cdot \mathrm{K}\right)$ for CEM III.

This parameter determined for specimens dried to constant mass shows some little dependence. Replacing $66 \%$ of the sand volume with copper slag without increasing the plasticizer dosage resulted in a reduction of the average value of volumetric thermal capacity by several percent (from $1.5 \%$ to $4.9 \%$ ). In turn, in series containing copper slag and an increased amount of plasticizer (series marked with suffix " $66 / \mathrm{F}$ "), the value of volumetric thermal capacity was very close to those obtained in case of the reference concrete. Apart from this minor dependence, it was found that 
the value of this parameter for this state of saturation of concrete is similar and equal approximately $1.71 \mathrm{MJ} /\left(\mathrm{m}^{3} \cdot \mathrm{K}\right)$ for all concretes.

In the case of specimens dried to a constant mass, the obtained results were characterized by a smaller dispersion compared to specimens saturated with water.

\section{Thermal diffusivity}

The obtained values of thermal diffusivity of the concretes are presented in Table 6.

Thermal diffusivity is a derivative of two previously described quantities. It is calculated as the quotient of the thermal conductivity coefficient and the volumetric thermal capacity. This value describes the rate at which thermal energy is transferred within a given medium between points with different temperatures. This parameter depends only on these two values, so its value can be partially predicted by analyzing its two components individually.

The distribution of the obtained thermal diffusivity values well reflects the trends describing the distribution of the thermal conduction coefficient values. The distribution of volumetric heat capacity results in this case is too small to significantly affect the thermal diffusivity values trends.

Table 6. Average values of thermal diffusivity of tested concretes depending on the state of saturation with water

\begin{tabular}{|c|c|c|c|c|c|c|c|c|c|c|}
\hline \multirow{2}{*}{ Condition } & \multirow{2}{*}{$\begin{array}{l}\text { Thermal diffu- } \\
\text { sivity }\left[\mathrm{mm}^{2} / \mathrm{s}\right]\end{array}$} & \multicolumn{9}{|c|}{ Concrete mixture designation } \\
\hline & & $\mathrm{I} / 0$ & $\mathrm{I} / 66$ & $\mathrm{I} / 66 / \mathrm{F}$ & $\mathrm{II} / 0$ & II/66 & $\mathrm{II} / 66 / \mathrm{F}$ & $\mathrm{III} / 0$ & $\mathrm{III} / 66$ & III/66/F \\
\hline \multirow{3}{*}{$\begin{array}{l}\text { Specimens fully } \\
\text { saturated with water }\end{array}$} & Mean & 1.27 & 1.23 & 1.20 & 0.99 & 0.93 & 0.95 & 0.97 & 0.95 & 0.95 \\
\hline & Stand. dev. & 0.04 & 0.09 & 0.10 & 0.06 & 0.08 & 0.06 & 0.08 & 0.09 & 0.05 \\
\hline & Averaged & \multicolumn{3}{|c|}{1.23} & \multicolumn{3}{|c|}{0.96} & \multicolumn{3}{|c|}{0.96} \\
\hline \multirow{3}{*}{$\begin{array}{l}\text { Specimens dried to } \\
\text { constant weight }\end{array}$} & Mean & 0.99 & 0.94 & 0.92 & 0.77 & 0.68 & 0.69 & 0.76 & 0.71 & 0.71 \\
\hline & Stand. dev. & 0.03 & 0.05 & 0.04 & 0.02 & 0.04 & 0.03 & 0.04 & 0.04 & 0.02 \\
\hline & Averaged & \multicolumn{3}{|c|}{0.95} & \multicolumn{3}{|c|}{0.71} & \multicolumn{3}{|c|}{0.72} \\
\hline
\end{tabular}

The highest values of the thermal diffusivity coefficient were obtained for concrete containing CEM I. For concrete based on CEM II and CEM III, however, significantly lower values were obtained compared to concrete with CEM I cement. The thermal diffusivity coefficient for CEM II and CEM II reached values very close to each other.

\section{Conclusions}

Replacing part of the fine aggregate with copper slag positively influenced the compressive strength of the concrete. An increase in compressive strength of up to $20 \%$ was observed. However, it was necessary to increase the amount of plasticizing admixture in order to obtain a consistency and workability similar to those for reference concrete.

The usage of copper slag did not significantly influence the tensile splitting strength of concrete. Only in one case, for series marked as I/66/F, there was a statistically significant increase of about 40.3\% (1.3 MPa).

The usage of copper slag contributed to lowering the thermal conductivity of hardened concrete. The decrease of the thermal conductivity coefficient values for concrete dried to constant mass was $3.0-5.1 \%$ for concrete with CEM I, 8.8-14.8\% for concrete with CEM II and 6.4-9.2\% for concrete with CEM III respectively.

Replacement of sand with copper slag has no effect on volumetric heat capacity in relation to the reference concrete. The values of the volumetric heat capacity showed no explicit trend in general. The values for concrete based on the same cement were similar to each other. All tested concrete mixtures in a dry state obtained similar value of this parameter. Its averaged value for all concrete mixtures was equal $1.71 \mathrm{MJ} /\left(\mathrm{m}^{3} \cdot \mathrm{K}\right)$. For saturated state there there was more variation in value. The avereged values for this parameter were equal: $1.91 \mathrm{MJ} /\left(\mathrm{m}^{3} \cdot \mathrm{K}\right)$ for $\mathrm{CEM} \mathrm{I}$, $1.87 \mathrm{MJ} /\left(\mathrm{m}^{3} \cdot \mathrm{K}\right)$ for CEM II and $1.78 \mathrm{MJ} /\left(\mathrm{m}^{3} \cdot \mathrm{K}\right)$ for CEM III.

The values of thermal diffusivity are well reflected in the values of thermal conductivity coefficient.

\section{Acknowledgements}

The work has been supported by the Town of Płock through the Mayor's Research Grants Programme "'Collaboration with Universities"'.

\section{References}

Al-Jabri, K. S., Al-Saidy, A. H., \& Taha, R. (2011). Effect of copper slag as a fine aggregate on the properties of cement mortars and concrete. Construction and Building Materials, 25(2), 933-938. https://doi.org/10.1016/j.conbuildmat.2010.06.090 
Al-Jabri, K. S., Hisada, M., Al-Saidy, A. H., \& Al-Oraimi, S. K. (2009). Performance of high strength concrete made with copper slag as a fine aggregate. Construction and Building Materials, 23(6), 2132-2140. https://doi.org/10.1016/j.conbuildmat.2008.12.013

Ambily, P. S., Umarani, C., Ravisankar, K., Ranjan, P., Bharatkumar, B. H., \& Iyer, N. R. (2015). Studies on ultra high performance concrete incorporating copper slag as fine aggregate. Construction and Building Materials, 77, 233-240. https://doi.org/10.1016/j.conbuildmat.2014.12.092

Applied Precision Ltd. (2011, 15 April). ISOMET 2114 Portable system for measurement of heat transfer properties of materials. Retrieved from https://www.appliedp.com/download/catalog/isomet_pc_en.pdf

Dhir, R. K., de Brito, J., Mangabhai, R., \& Lye, C. Q. (2017). Sustainable construction materials-copper slag. Cambridge: Woodhead Publishing. https://doi.org/10.1016/B978-0-08-100986-4.00001-8

Jaskulski, R., \& Kubissa, W. (2018). Lightweight concrete with copper slag waste as sand substitution. In MATEC Web of Conferences (vol. 163). https://doi.org/10.1051/matecconf/201816303006

Jaskulski, R., \& Kubissa, W. (2019). Mechanical properties of copper slag waste based CLSM mixtures. In 13th International Conference "Modern Building Materials, Structures and Techniques", 16-17 May 2019, Vilnius, Lithuania (in press).

Jaskulski, R., Reiterman, P., \& Kubissa, W. (2017). Investigation of thermal properties of concrete with recycled aggregate and concrete with copper slag and supplementary cementing materials. In I. Hager (Ed.), Energy efficient, sustainable building materials and products (pp. 283-302). Cracow: Cracow University of Technology.

Kubissa, W., Jaskulski, R., Ng, P.-L., \& Chen, J. (2018). Utilisation of copper slag waste and heavy-weight aggregates for production of pre-cast shielding concrete elements. Journal of Sustainable Architecture and Civil Engineering, 22(1), 39-47. https://doi.org/10.5755/j01.sace.22.1.20006

Kubissa, W., Jaskulski, R., \& Simon, T. (2017). Surface blast-cleaning waste as a replacement of fine aggregate in concrete. Architecture Civil Engineering Environment, 3, 89-94. https://doi.org/10.21307/acee-2017-038

Kuterasińska, J., \& Król, A. (2015). Mechanical properties of alkali-acivated binders based on copper slag. Architecture Civil Engineering Environment, 8(3), 61-67.

Murari, K., Siddique, R., \& Jain, K. K. (2015). Use of waste copper slag, a sustainable material. Journal of Material Cycles and Waste Management, 17(1), 13-26. https://doi.org/10.1007/s10163-014-0254-x

Polish Committee for Standardization. (2011a). Testing fresh concrete - Part 5: Flow table test (PN-EN 12350-5).

Polish Committee for Standardization. (2011b). Testing hardened concrete. Making and curing specimens for strength tests (PNEN 12390-2).

Polish Committee for Standardization. (2011c). Testing hardened concrete. Compressive strength of test specimens (PN-EN 12390-3).

Polish Committee for Standardization. (2011d). Testing hardened concrete. Tensile splitting strength of test specimens (PN-EN 12390-6).

Polish Committee for Standardization. (2011e). Cement - Part 1: Composition, specifications and conformity criteria for common cements (PN-EN 197-1).

Polish Committee for Standardization. (2012). Admixtures for concrete, mortar and grout. Concrete admixtures. Definitions, requirements, conformity, marking and labelling (PN-EN 934-2).

Prem, P. R., Verma, M., \& Ambily, P. S. (2018). Sustainable cleaner production of concrete with high volume copper slag. Journal of Cleaner Production, 193, 43-58. https://doi.org/10.1016/j.jclepro.2018.04.245

Shi, C., Meyer, C., \& Behnood, A. (2008). Utilization of copper slag in cement and concrete. Resources, Conservation and Recycling, 52(10), 1115-1120. https://doi.org/10.1016/j.resconrec.2008.06.008 